\title{
TWEENERS - THE NEXGEN SHOPPERS
}

\author{
Neena Prasad*
}



* Lecturer, Post Graduate Department of Management Studies, Dayananda Sagar. College of Engineering, Kumaraswamy Layout, Bangalore : 560078. 
A survey which involves the use of Questionnaire for interviewing the respondents on the various factors connected to this study was carried out and an analysis using suitable statistical techniques was done.

Key words: Family, Peer pressure, Media influence or Advertising effectiveness and Visual content, Purchasing power

\section{Introduction}

'Consumer is Kingll', is the moolah of the modern day marketers. Consumers are traditionally considered an important basis for market segmentation. When a firm decides to operate in two or more age segments of a market, the focus automatically shifts to children. Children vary enormously not only in abilities and capacities but also in socio-economic and cultural characteristics. The nature of childhood changes as the society evolves. Children are more sophisticated than their parents in the knowledge of the market and its product offerings. Their ability to navigate among brands is noteworthy because it is this critical factor which acknowledges the fact that heterogeneity exists and this can be illustrated by the existing diversity in the context of their cognitive and social development. Greater variability can also be seen very prominently in their social circumstances where they attend schools of varying quality and belief systems which in turn paves way for a varied media experiences, interests, sophistication and motivation. Thus it is very difficult to generalize about the developmental stages, tastes, interests and the social contexts of the different groups of children. However the challenge for the marketer is to better understand the different developmental stages of children. This group itself consists of three to four sub-groups, namely; Infants, Kids, Tweens and Teens. This paper focuses on the TWEENS aged between 8-13 years. It studies the factors that characterize the marketers' strategy on how they target the children to promote or push their product (ethical or non-ethical ways is an out of reach factor). A study has been carried out to examine to what extent are 'TWEENS' who are well defined and distinguished, a separate audience group for the marketers?

Tweens is a colloquial label for the phenomenon of children who perceive themselves or are perceived by others as 'in between' childhood and adolescence. It is not a precise term. They represent quite a significant 
figure not only in terms of the country's census figures but also in terms of market especially the consumer market. That is to say that they are the easy and most vulnerable target but a powerful audience group for the marketers to understand and influence. The all pervading consumerism culture is propelling these tweens to face challenges of adolescence prematurely. It is a common perception that the current tweens are much more matured and grown up than the tweens a decade and a half back. They are more self-conscious, more demanding and have high hand in the decision making process within the household. The most important thing that is to be taken note of is the fact that they compare themselves with the well heeled celebrity models in the field of filmdom or sports or even the corporate world. This process of identifying oneself with the role models kick starts with tweens. The most important reason being the media plays a very influential role especially in the case of children. Before the advent of television, the role models were people close to home in the roles of mother, father, grandparents or teachers. Now it is the media which decides these young customers' choice behaviour. Its the most pervading factor for providing information about the market and its offerings. The availability of information through sources like internet to this net savvy group is like opening a pandora's box of wishes which pushes the 'Good, Bad and Ugly' offerings of the market to the unsuspecting young audience.

Technology is one very important parameter which holds the whole world at ransom as it enables product innovation which in turn kindles product competition in terms of features, value additions, price and soon. In today's market along with technology \& innovation another predominant term that occupies a critical position is 'SPEED'. Marketers have to link with speed with 'LOOK WHILE YOU LEAP' attitude instead of 'LOOK BEFORE YOU LEAP'.

Therefore, technology, innovation \& speed turns out to be a marketer's constant companion in gratifying the ever novelty seeking \& necessity satisfying attifude of an average Indian who is bound to ensure that Consumer India is always receptive to Innovations - the important Pre-requisite for the introduction of new brands, new products, innovated products \& new shopping formats. Branding is just a nomenclature of the company or the product/services that the marketer makes use of to make a sales proposal.

Everybody wants to enjoy, make merry, thanks to the zooming sensex and booming Economy. Celebration is one excuse that is always in the air and 
it seems to be the only constant these days which we just can't afford to miss it even if we were on the other planet. Thanks to Archies greetings who have popularized, a theme for every selling proposition - Father's Day, Mother's Day, Boss's Day, Friendship Day \& so on... Malls, Shopping sprees, Weekend getaways, Festival plans, Gold rush et al are all the oft repeated words of this season which goes hand in hand with the Unique shopping experience captured in a glass walled fortress - The Malls. Outside this unique Brand centric place, there is chaos everywhere, snarling traffic jams, haphazard movement of all 2, 3, 4 wheelers \& pedestrians. Inside the glass walled fortress of India's new prosperity, it's a whole new world, equally chaotic but with a difference. Flashing neon lights, blaring indi-pop or western tracks create one hell of a confusion along with young girls \& boys hawking out the brand nomenclature from a stage, customers moving aimlessly from here to there looking at the price tags, brandnames, quality of the wares add to the confusion exponentially. This is a place where all big international as well as national brands are advertised. Advertising for good or for bad, surely rules our psyche. Advertising and branding plays a very important role in a metro-morphosised human being -Tweens. For any marketer Tweens acts as the most trusted barometer for measuring the changing attitudes. Because this sect can feel and experience the impact of advertisements to the maximum level. However, the age of brainwashing to buy a product/brand seems to have taken a back seat with the Tweens being highly brand conscious, even the low involvement category like pens are endorsed by celebrities in order to woo the youth. The level of influence Big B, Our Master Blaster, Shah Rukh Khan \& so on are some of the few. The marvels of technology and miniaturization has made a very big impact on them. The ipods, MP3s, high-end music systems, Cell-phones with value additions etc have caught the fancy of GENEXT for which the Brand managers and marketers are turning the world upside down to woo them. But the real appeal of owning these highend products lies in the indefinable design that grabs the attention of these consumers instantaneously which is the main reason for the success of the brands like Samsung, Nokia, Motorola, Apple, Sony, Nike, Reebok etc. By this we come to know that the nextgen is a generation spoilt for choice of brands, products \& media. Brand proliferation, rapidly changing retail scenario \& technology boom acts as a catalyst for the highly knowledgeable, more demanding, more experimentative and less brand loyal generation. In order to be a step or two ahead of the genext, the marketers should wake up with a jolt to the whole new world of opportunities in the market. 
The drastically evolving society of ours has induced a high to very high degree of Socialization. The initiators are usually socialization agents like the family, peers and the media. The family specific factors are parental lifestyle (reasonably affluent) which is generally influenced by the education level \& monetary status, the orientation of the family to a communication paradigm in the context of the changing socio economic and cultural environment.

For example: it is very common to have a double income household which ensures comfort in' all the possible ways to the kids - tweens.

The other very important socializing agent is the peer influence which takes the centre stage. This is a noteworthy factor because in this new age of nuclear families with a one child norm, it is but natural for child to turn to friends for company. This is a phase of life which is full of peer pressure. This has indirectly or directly harboured an unconscious competitive spirit in the young minds that when his fellow classmate or a friend has a particular gizmo or a product like computer games or movie CDs for that matter, why shouldn't I? The criticality of this issue has been catched on by the guerillian marketers and advertisers by employing a persuasive medium of communication. Their main objective is to provide information of the product by associating the product with fun and happiness thereby trying to create a positive attitude towards the market and its product offerings. This age group is particularly targeted because the ability to distinguish between the good and bad, biased, deceptive ads is not present and they have a very wavering vision for identifying the real life and a simulated life. Hence, they become the soft targets for all the subtle tactics of the marketers or the advertisers or sometimes both virtually everywhere be it in classroom or textbooks or internet or rather any identifiable place of the tweens. Media has an upper hand influence in this issue. The marketers attract the attention of their target audience by using celebrities as endorsers or brand ambassadors which in the process leads to idealizing the role models, like for instance, Shah Rukh Khan, Sachin or our evergreen endorser Amitabh Bachhan. In the melee, Tweens become more knowledgeable about the market and its offerings. However, media eventhough a very important factor alone can never be considered the main deciding factor.

Although, Tweens can't drive, vote, buy directly, they are nonetheless a significant consumer group. They have adopted a strategy which involves nagging, persuasiveness and so on with the parents, although parents deny 
the claim, they do admit that some of the tween strategies are very effective. These strategies are put to use as a reward for getting good marks at school. According to the parents and marketers they believe that all this fosters self esteem and acts as a self motivator.

\section{Objective}

It is universally known that the three very important socializing agents are family, peers and media. This paper tries to find out which one out of these three agents influence the most for a tween to make a choice purchase. The following are the objectives of the research study.

- To determine the factors influencing the brand awareness level of the tweens.

- To determine the factors influencing the choice purchase behaviour of the tweens

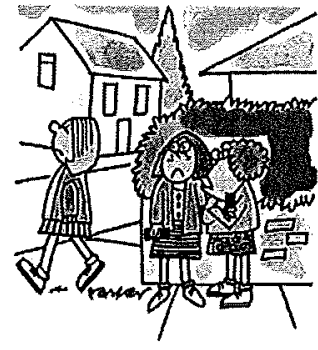

"Eight years old and no mobilc!"

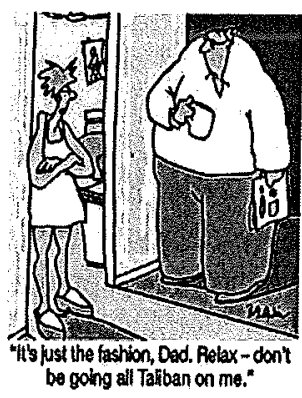

be going all Talban on me."

\section{Research Methodology}

- A survey method is used for collecting the primary data.

- The primary data was collected using a pre-tested questionnaire.

- A combination of well structured as well as unstructured questions were used in the questionnaire.

- Indepth interview technique was employed.

- A sample size of 90 respondents were selected for the survey.

- The respondents were in the age group of 8-13 years of age. 
- Convenient sampling technique was used for the research study.

- The secondary data has been collected through internet, marketing journals, business magazines and the news dailies.

- A formal study has also been used by formulating the hypothesis and testing it by using Pearson's Chi-square test to solve the research questions.

\section{Review of Previous Studies}

It is well recognized that adolescence is a time of growth, maturity, socialization, and reanalyzing of one's self (Peterson, 1987). It is a time of transition from childhood to adulthood, which also means a period of redefining of perceived expectations. This development of a new understanding of one's identity comes from several cues, such as family, peers, work, and society (Grotevant, 1987; Peterson, 1987; Jones, Vigfusdottir \& Lee, 2004; Reiss \& Youniss, 2004). The process is sparked by social interaction and the cues are then internalized and evaluated before a decision as to whether or not to identify with the action is made. Pressures laid on adolescents from peers include rigidity in what each role or influencer place upon adolescents the flexibility remains in the overall choices finally reached in each arena of life. The development of selfidentity is an ever changing and continuous discovery (Reiss \& Youniss, 2004). By listening to their friends they are able show independence from their parents while maintaining a feeling of conformity and solidarity within their peer groups (Wilson, MacGillivray, 1998). It is often with friends that adolescents feel most comfortable expressing their ideas as well as exploring new options (Akers \& Jones \& Coyl, 1998). Akers et al., conducted a study that found that "best friends" are similar in issues such as dating and friendships. Their findings support the idea that friends are alike in specific life contexts. Along with the desire to expand their freedom from the regulations by family, the security of the "right" friends is just as important. Being seen as "cool" which is often equivalent to looking good is the primary worry to over half of the students researched by Teenage Research Unlimited (Schlossberg, 200). Reiss and Youniss (2004) explore in depth the idea of family members losing influence and peers gaining importance during adolescence. Using Erikson's idea on identity development they observe high school students and hypothesize that in order to discover one's self, a degree of separation from parents will be parallel to an increase of control by peers. Although they did find an increase over the 
years in communication with friends, mothers continued to play an integral role in support. As tweens is seen as a "moratorium" where the experimentation of ideals is encouraged (Peterson, 1987). Several studies note that, as young tweens become older teens, they try to gain their own identity and parents begin to have less influence over them. Steven Mc Chug and Rebecca Holdorf analyse the tween behaviour in the context of the clothing. The pattern of the behaviour exhibited in terms of choice which includes latest styles which are immortalized by their role models. Lynn Phillip and Brian $S$ in their research conducted a study on the age difference in information processing - a perspective on the consumers of different ages states that tastes, likings role models, purchasing behaviour all are not static. It is constantly evolving with the changing times. As the society evolves itself to the top rungs, the consumer behaviour, the markets also changes accordingly. The younger generation are born to buy according to Julius B Schor in his book 'Born to Buy-Commercialised Child and New consumer culture'.

In the context of the previous studies conducted, this research paper tries to emulate the predominant constructs from the previous research studies in the Indian context and tries to analyse it in the paper.

\section{Analysis}

In order to solve the research problem, we have to find out the factors and the relationship between them in the context of brand awareness levels, influencers and the purchasing power. It is found that parents, peers and advertisements were the main influencing factors. The research findings were analysed by making use of the chisquare test and the test results are noted down in the table no $I$.

\section{Brand Awareness Level}

Hypothesis: 1

\section{Relationship between the Advertisements and Brand Awareness levels}

$H_{0}$ : There is no significant relationship between the advertisements and brand awareness levels among tweens. 
$H_{1}$ : There is a significant relationship between the advertisements and brand awareness levels among tweens.

Pearson's Chi-square test clearly shows that there is a significant relationship between the advertisements and the brand awareness levels. Hence the null hypothesis $\mathrm{H}_{\mathrm{o}}$ is rejected.

It was found out that most of the respondents were well aware of the popular brands. The tweens were avid TV viewers. They were also well versed in the brand names and this awareness is brought about by the newspapers, magazines and hoardings. It was also found out that the socialising agent media particularly advertisements (print and visual media) were very much appealing attention seeking and vibrant to them because of the celebrity who's endorsing it, colour, the locales and the captions to a very large extent.

$\begin{array}{ll}\text { For ex: Domino's } & : \text { "Hungry Kya." } \\ \begin{array}{ll}\text { Maggi noodles } \\ \text { Lays Chips }\end{array} & : \text { "Taste Bhi, Health bhi." } \\ & \end{array}$

Hypothesis: II

\section{Relationship between peer influence and brand awareness levels}

$H_{\circ}$ : There is no significant relationship between peer influence and brand awareness levels among tweens.

$\mathrm{H}_{1}$ : There is a significant relationship between the peer influence and brand awareness levels among tweens.

Pearson's Chi-square test clearly shows that there is a very significant relationship between the peer influence and the brand awareness levels.

This socialising agent commanded a very large percentage of influencing power amongst tweens. The word of mouth played a very critical role in this issue. The main reason for this agent to be very dominant is because of the advertisements. The advertisers endorse kids in the ads which in turn becomes a fad for the tweens to copy the same lifestyle in reality. Brand awareness was maximum because the communication levels in the tweens regarding the market, its products and the advertisements related to them were significantly high. 
Hypothesis: III

\section{Relationship between family and brand awareness levels}

$H_{0}$ : There is no significant relationship between the influence by the family and the brand awareness levels.

$\mathrm{H}_{1}$ : There is a definite relationship between the influence by the family and the brand awareness levels.

Pearson's Chi square test clearly shows that there is no relevance in the relationship between the parental influence and the brand awareness levels of the tweens. In this study the family as an influencer can be interpreted in terms of the income of the household. The household may be a single or a double incomed one. Likewise the psychology of the tweens also change. This hypothesis does not support strongly either of the relationship between the income of the parents on the family as the decider for brand awareness levels in the tweens. Hence the hypothesis that the relationship between the family and the brand awareness levels is non-existent/not applicable as per this study.

\section{Purchasing Power of the Tweens}

Hypothesis: I

Relationship between advertisements and the choice purchase behaviour.

$\mathrm{H}_{\mathrm{o}}$ : There is no significant relationship between the advertisements and the choice purchase behaviour among the tweens.

$\mathrm{H}_{1}$ : There is a significant relationship between the advertisements and the choice purchase behaviour among the tweens.

Pearson's Chi-square test clearly shows that there is a significant relationship between the advertisements and the choice purchase behaviour among the tweens. Hence the null hypothesis $\mathrm{H}_{0}$ is rejected.

It was found out that most of the respondents were well aware of the popular brands. The tweens were avid TV viewers and were also well versed in the brand nomenclature. It was also found out that the socialising agent media particularly advertisements (print and visual media) influenced 
them to purchase their choice of particular brands. The media particularly advertisements acted as a active factor in the tweens' Choice purchase behaviour.

\section{Hypothesis: II}

Relationship between peer influence and the choice purchase behaviour.

$H_{0}$ : There is no significant relationship between the peer influence and the choice purchase behaviour among the tweens.

$\mathrm{H}_{1}$ : There is a significant relationship between the peer influence and the choice purchase behaviour among the tweens.

Pearson's Chi-square test clearly shows that there is a significant relationship between the advertisements and the choice purchase behaviour among the tweens. Hence the null hypothesis $H_{0}$ is rejected.

It was found out that there was a very large percentage of tweens who were very close to their friends. It was also found out that any decision in connection to purchasing a product or ownership of the product depended on their communication with their friends which involved discussion of products they want to purchase, the brand perfectly appropriate for them, the colour, the features and so on. It was either an ownership of a similar product or a product with additional competitive features. The choice purchase behaviour significantly influenced by this socializing agent. There were no other agent which was so powerful as this one.

Hypothesis: III

\section{Relationship between family and the choice purchase behaviour}

$H_{0}$ : There is no significant relationship between the family and the choice purchase behaviour among the tweens.

$H_{1}$ : There is a definite relationship between the family and the choice purchase behaviour among the tweens.

Pearson's Chi-square test clearly shows that there is a significant relationship between the family and the choice purchase behaviour among the tweens. Hence the null hypothesis $H_{0}$ is rejected. 
It was found out that this socializing agent had a significant influence in the purchase behaviour of the tweens. The relationship of tweens in the family as an influencer in the purchase behaviour can be simply explained in one term 'Pester Power'. This was predominant and it did not make much difference whether it was a dual or a single income household. However, the total income from a dual household did matter in a very few cases as per the tweens were concerned. The tweens since they are well aware of the market were consulted and it was their final decision which was considerd for the purchase. This as per the study was the onslaught of the media (advertisements) in to each and every household.

\section{Consolidated Test Results}

\section{Tweeners - The Nexgen Shoppers}

Table No: 1

\begin{tabular}{|c|c|c|c|c|l|}
\hline SI & $\begin{array}{c}\text { Independent } \\
\text { Variable }\end{array}$ & $\begin{array}{c}\text { Dependent } \\
\text { Variable }\end{array}$ & $\begin{array}{c}\text { Test } \\
\text { Used }\end{array}$ & $\begin{array}{c}\text { Chi } \\
\text { Square } \\
\text { Value }\end{array}$ & Result \\
\hline 1. & Media & $\begin{array}{c}\text { Brand } \\
\text { Awareness } \\
\text { Level }\end{array}$ & $\begin{array}{c}\text { Chi } \\
\text { Square }\end{array}$ & $3.3068^{*}$ & $\begin{array}{l}\text { There is a significant } \\
\text { relationship between } \\
\text { media and brand } \\
\text { awareness level among } \\
\text { the respondents }\end{array}$ \\
\hline 2. & Peers & $\begin{array}{c}\text { Brand } \\
\text { Awareness } \\
\text { Level }\end{array}$ & $\begin{array}{c}\text { Chi } \\
\text { Square }\end{array}$ & $39.736^{* *}$ & $\begin{array}{l}\text { There is a significant } \\
\text { relationship between } \\
\text { peer influence and } \\
\text { brand awareness level } \\
\text { among the respondents. }\end{array}$ \\
\hline 3. & Family & $\begin{array}{c}\text { Brand } \\
\text { Awareness } \\
\text { Level }\end{array}$ & $\begin{array}{c}\text { Chi } \\
\text { Square }\end{array}$ & $25.2706^{* * *}$ & $\begin{array}{l}\text { There is a significant } \\
\text { relationship between } \\
\text { family and brand } \\
\text { awareness level among } \\
\text { the respondents. }\end{array}$ \\
\hline
\end{tabular}




\begin{tabular}{|c|c|c|c|c|l|}
\hline $\begin{array}{l}\text { SI } \\
\text { No. }\end{array}$ & $\begin{array}{c}\text { Independent } \\
\text { Variable }\end{array}$ & $\begin{array}{c}\text { Dependent } \\
\text { Variable }\end{array}$ & $\begin{array}{c}\text { Test } \\
\text { Used }\end{array}$ & $\begin{array}{c}\text { Chi } \\
\text { Square } \\
\text { Value }\end{array}$ & Result \\
\hline 4. & Media & $\begin{array}{c}\text { Purchasing } \\
\text { Power }\end{array}$ & $\begin{array}{c}\text { Chi } \\
\text { Square }\end{array}$ & $20.81^{* *}$ & $\begin{array}{l}\text { There is a significant } \\
\text { relationship between } \\
\text { media and the } \\
\text { purchasing power } \\
\text { among the respondents. }\end{array}$ \\
\hline 5. & Peers & $\begin{array}{c}\text { Purchasing } \\
\text { Power }\end{array}$ & $\begin{array}{c}\text { Chi } \\
\text { Square }\end{array}$ & $2.555^{*}$ & $\begin{array}{l}\text { There is a significant } \\
\text { relationship between } \\
\text { peer influence and the } \\
\text { purchasing power } \\
\text { among the respondents. }\end{array}$ \\
\hline 6. & Family & Purchasing \\
Power & $\begin{array}{c}\text { Chi } \\
\text { Square }\end{array}$ & $1.987^{*}$ & $\begin{array}{l}\text { There is a significant } \\
\text { relationship between } \\
\text { family and the } \\
\text { purchasing power } \\
\text { among the respondents. }\end{array}$ \\
\hline
\end{tabular}

Critical values at 4 degrees of freedom at $90 \%$ level of significance is 1.064 and at $10 \%$ level of significance is 7.779 .

* indicates significance of the calculated value at $90 \%$,

** indicates significance of the calculated value at $10 \%$.

The research findings were further analysed using Pearson's method of correlation and it was found out that there was a very high degree of correlation between the factors - media \& peers (whose correlation coefficient was around $r=0.9702$ ). A similar result was also obtained with factors - media \& family (whose correlation co-efficient was around $r=0.9048$ ). Therefore, in the context of this research study the main determinants of the purchasing power of tweens and their brand awareness are media (advertisements), peer influence and family. 


\section{Sources of Brand Awareness}

- Audio and visual Media-Radio and Television.

- Print Media - Newspapers, Popular Magazines, Hoardings.

- Word of Mouth Communication - Family/Friends.

- Retail Store outlets - Interactive Brand Experiences.

The respondents i.e the tweens are more communicative and receptive to the innovative and creative messages delivered by the media. They are highly motivated by the advertisements on the print and audio-visual media to make a purchase proposal, but this motivation need not necessarily give rise to an impulse buying always. The tweens are very choosy about the products they purchase. Therefore, the marketers and advertisers have to be very careful while communicating the brand qualities and image to their potential young and dynamic customers because it is a matter of survival in the market which breathes competition (a cut throat competition) right under its nose. Pester power is one of the most important construct in this study which influences the purchase behaviour of the tweens. Most of the respondents are brand savvy and majority of them are aware of the brand kinesthetics through print, audio \& visual, retail store outlets and word of mouth communication.

\section{Limitations}

- The questionnaire for the research study has been designed only with variables like media(advertisements), peers $\&$ family as the main criteria for determining the brand awareness levels \& the choice purchase behaviour of the tweens.

- The research study is confined to only a selected fraction of the population of the tweens in the city of Bangalore with the sample size of 90 respondents. This is not a true representation of the tween population as a whole.

- Ignorance on the part of the respondent and time-constraint are some of the limitations of this study. 


\section{THE ROAD AHEAD....}

The increasing dominance of the simulated world over the real world in a tweens' daily experience has been noticed to have a greater impact on the brand awareness level and the choice purchase behaviour of the tweens. The present and the future era belongs to the younger generation. With revolution brewing in the world of communications- Internet, Mobile telephony, ipods etc, marketers need to be more consumer centric and cocreate brands and products with consumers rather than following consumer's needs \& wants. They should always be evolving and innovative in order to retain these highly mobile, well heeled, fickle minded with a don't care attitude class of consumers. There is an overload of information, overload of brands \& products, overload of advertisements \& promotions to be handled by them because of the tremendous size of the market. So if a marketer has to connect to this tween generation, he has to do so by making Advertising as a link vehicle between the marketer and the brand in such a way that the advertisements should not corrupt the minds but instead should ignite them on the values of our socio \& cultural system and thus create a brand loyalist.

\section{References}

1. Sapna Shetty, "Refail \& Shopper Trends"- A. C. Nielson report: 2004 Business Today - July 182004.

2. Dr. Y. L. R. Moorth, "Brands Value Matter More Than The Origin"- DH Economy \& Business - July 112005.

3. Extracts from "Marketers' Barometer", Brand Equily - The Economic Times-Oct 19 2005.

4. Internet - www.consumerism.com, www.marketresearch.com.

5. Prof. Rajendra Nargundkar, Marketing Research - Text and cases.

6. Julius B Schor, Born to Buy - Commercialised child and New consumer culture.

7. Lynn W Phillip \& Brian S, Age difference in information processing - a perspective on the consumer behaviour at different ages.

8. Simpson, Douglas \& Schimond, Tween Paradigms.

9. Steven McChug \& Rebecca Holdorf, The role of teen oriented fashion magazine content on clothing purchasing behaviour and attitude of Adolescents and teens. 